\title{
The nomenclature of the Recent Pentastomida (Crustacea), with a list of species and available names: Corrigendum
}

\author{
Gary C. B. Poore
}

Received: 23 July 2012 / Accepted: 24 July 2012

(C) Springer Science+Business Media B.V. 2012

Shipley's (1905) use and justification of the crustacean subclass name Pentastomida now in common use was not the first usage of this name, as I stated in my recent paper (Poore, 2012). The name Pentastomida can be traced back at least to Huxley (1869) by searching the Biodiversity Heritage Library (http://www.bio diversitylibrary.org/). Huxley listed the name as a member of Arachnida in his book 'An introduction to the classification of animals' without giving its derivation or referring to earlier literature. In a later work, he (Huxley, 1878) included two generic names, Linguatula Frölich, 1789 and Pentastoma Rudolphi, 1812 , as synonyms. Huxley's name was used later in the 19th Century in general texts (for example, Kingsley, 1884; Sedgwick \& Heathcote, 1884) and in a comparative embryology textbook (Balfour, 1880). The order Linguatulida Claus, 1872 is a synonym no longer in use. Curiously, no-one describing species of this taxon during the 18th or 19th Centuries (see references to Frölich, Humboldt, Diesing, Wyman, Haldeman, Baird, Leuckart, Wedl and Lohrmann in my 2012 paper) used either higher taxon name. Diesing (1836), who has been commonly but wrongly credited with authorship of the name Pentastomida, discussed only the genus Pentastoma, placing it alone in a new order, Acanthotheca.

\section{G. C. B. Poore $(\bowtie)$}

Museum Victoria, GPO Box 666, Melbourne,

VIC 3001, Australia

e-mail: gpoore@museum.vic.gov.au
Acknowledgement I thank Rod D. M. Page for alerting me to early uses of this name.

\section{References}

Balfour, F. M. (1880). A treatise on comparative embryology. London: Macmillan, Vol. 1, $492+$ xxii pp.

Claus, C. (1872). Grundzüge der Zoologie. Zum gebrauche an universitäten und höheren lehranstalten sowie zum selbststudium. (2nd Ed.) Marburg \& Leipzig: N.G. Elwert, $1170 \mathrm{pp}$.

Diesing, K. M. (1836). Versuch einer Monographie der Gattung Pentastoma. Annalen des Wiener Museums der Naturgeschichte, 1, 1-32.

Frölich, J. A. (1789). Beschreibungen einiger neuen Eingeweidewürmer. Der Naturforscher, 24, 101-162.

Huxley, T. H. (1869). An introduction to the classification of animals. London: Churchill \& Sons, $147 \mathrm{pp}$.

Huxley, T. H. (1878). A manual of the anatomy of invertebrated animals. London: Churchill \& Sons, 596 pp.

Kingsley, J. S. (Ed.). (1884). The standard natural history Vol. 2. Crustacea and insects. Boston: Cassino \& Co., 555 pp.

Poore, G. C. B. (2012). The nomenclature of the Recent Pentastomida (Crustacea), with a list of species and available names. Systematic Parasitology, 82, 211-240.

Rudolphi, C. A. (1812). Erster Nachtrag zu meiner Naturgeschichte der Eingeweidewürmer. Magazin der Gesellschaft Naturforschender Freunde zu Berlin, 6, 83-113.

Sedgwick, A., \& Heathcote, F. G. (Eds.). (1884). Elementary text-book of zoology.Vol. 1. General part and special part: Protozoa to Insecta. (Translated and edited from C. Claus). New York: Macmillan, 615 pp.

Shipley, A. E. (1905). Notes on ento-parasites from the Zoological Gardens, London, and elsewhere. Proceedings of the Zoological Society of London, 1, 248-253. 